the last conference in May 1971, for the 83 members of Intelsat under the temporary arrangements to produce their signatures to the permanent agreement. But it has been slow going. At the beginning of this week, six signatures were still lacking.

Why the reluctance to sign? It is the smaller countries which have been holding out. The accord of May 1971 stipulated that in order to take effect, the permanent arrangements for Intelsat must be ratified within 18 months by, first, two-thirds of the countries holding at least two-thirds of the investment shares in the satellite system as it exists now and, second, two-thirds of all the countries which were members of Intelsat in May 1971. The heavy investors in Intelsat, chiefly the United States, but Britain and Canada and Australia as well, signed straight away. They had no doubts about wanting Intelsat to continue as an organization which gave greatest influence to the heaviest users of satellite communication, like themselves (although the Americans were disappointed not to keep through Comsat, the private American satellite company, their overwhelming dominance of Intelsat). France held out a long while. It would have liked an Intelsat more favourable to Europe, but finally realized that there was no alternative. But smaller countries have been more emphatically unenthusiastic. They have little voice in Intelsat. They will be allowed to turn up every now and again to express their opinions in a kind of General Assembly but will have no real voice in what kinds of satellites are bought or what the rates are. That disenchantment (plus, to be sure, the slow process of having an international agreement ratified by 83 countries, each in its own chosen way) is what has dragged Intelsat down to the wire.

The deadline will probably be met and Intelsat will gradually assume the formal four-tiered structure agreed upon. If it is not, the 1971 agreement specifies that Intelsat will remain under its interim arrangements under which Comsat is both manager and majority shareholder. In theory, Comsat might not mind this state of affairs. But in fact it does not want to be seen to be in a muddle with its international business just as it is desperately trying to persuade the Federal Communications Commission to let it run at least one corner of an American domestic satellite service. If the accord of 1971 should collapse, then Intelsat itself might collapse. Or Comsat might be forced back into negotiations which would reduce its investment in Intelsat even further than the 1971 agreement.

\section{Rutherford, Grand Old Man}

THE Notes and Records of the Royal Society, usually a miscellaneous collection of jottings which will no doubt in future be less entertaining than they have been because of the death of Sir Harold Hartley, consist this current issue of a reprint of some of the papers read at some of the celebrations of the centenary of Rutherford's birth on October 28, 1971. At some point in the future, when people will be as concerned to understand why Rutherford was at once so successful and so influential as historians are now to know why Faraday made such a mark, this issue (Notes and Records, 27, 1; 1972) will be of some assistance, if only because it is more anecdotal than many of the accounts of Rutherford's life and work so far to appear, even more rich in personal detail than Eve's biography (Cambridge University Press, 1939). By all appearances, it seems as if the Royal Society was able to persuade several of Rutherford's collaborators, initially his research students, to attend the centenary celebrations only if they were prepared to let their hair down. The result is that Lord Blackett, the most laconic of them, acknowledges the zeal with which Rutherford sought to keep his colleagues' energies concentrated on atomic nuclei, and his discontent when some even among the brighter of them chose to go off elsewhere. No doubt it is now beyond dispute that Rutherford was the kind of experimental physicist who can only previously have had one peer-Faraday--and it is no great surprise to find, in the lectures at the centenary celebration, that Rutherford emerges as a kind of curmudgeon among physicists, able to say that theoretical physicists "play games with their symbols but we in the Cavendish turn out the real facts of nature". To be sure, Sir Nevill Mott does his best to make Rutherford seem a little like the stereotype of the bullheaded experimentalist and he and other contributors to the celebrations may be right when they imply that the secret of Rutherford's success was not so much his indifference to theory as his flair for formulating his own personal representations of theory quickly and in a usable form. The truth is, of course, that there can be no field of science in which the progress of understanding can be held to depend exclusively on either experiment or theory.

\section{Years Ago}

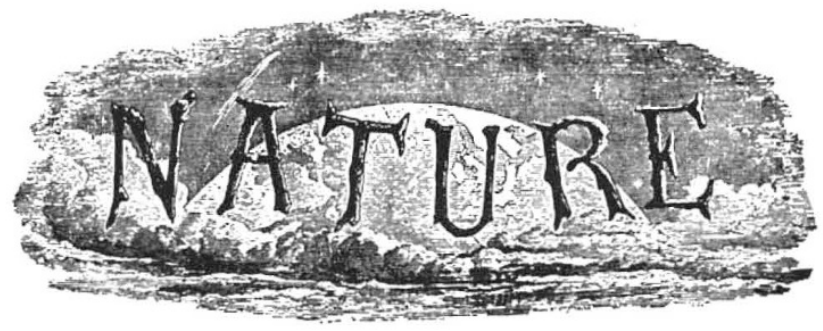

The Greenwich Date

UNDER this heading, in your number for Nov, 28, a letter signed "James Pearson" ends thus:- "The query then is-in what part of the globe and in what meridian does October 20 end and October $2 \mathbf{I}$ begin?" As well ask where a circle ends and where it begins. See an article at the end of Bayle's Dictionary, entitled, in the second Rotterdam edition, I 702," Dissertation sur le jour," vol. iii. p. 3I I 8 ; in the London edition, I 74I, "Dissertation concerning the Space of Time called Day," vol. $x$. p. 365. The difficulty, as Bayle shows, is in the nature of things. Let an equatorial railroad go round the world in twen!yfour hours, with a station at every $45^{\text {th }}$ meridian. At noon of October 20, Mr. West takes "a return ticket" westward; Mr. East take; one eastward. Both reckon by solar time. At every station Mr. West finds it noon, and on his return home reckons noon October 20 ; but the station-master reckons noon October 2I. Mr. East at $45^{\circ}$ sees the sun set at $60^{\prime}$ clock. At $90^{\circ}$ he finds midnight; at $135^{\circ}$ the sun rises at $60^{\prime}$ clock on October 21 ; at $180^{\circ}$ it is noon. Here the two passengers pass each other, $\mathrm{Mr}$. West reckoning it to be noon of October 20, Mr. East noon of October $2 \mathrm{I}$. At $\mathrm{I} 35^{\circ} \mathrm{WV}$., Mr. Last sees the sun set , at $90^{\circ}$ he finds midnight; at $45^{\circ}$ the sun rises at 6 o'clock on October 22. On his return home Mr. East reckons it to be noon of October 22. Here then are three different reckonings, and practically the keeping of Sunday, Christmas Day, Sc., on different days in different countries exists at this instant and must exist for ever. Practically also those who sail eastward round the world get one more dinner than those who stay at home. Those who sail westward round the world get one dinner less than those who stay at home, and two climers less than those who sail eastward, when both voyages are completed.

Brookwood Park, Alresford, Nov. $3^{\circ}$ Georar Greevivool)

From Nature, 7, 105, December 12, 1872. 